\title{
Immunohistochemical study of genital and extragenital forms of canine transmissible venereal tumor in Brazil ${ }^{1}$
}

\author{
Mariana B. Mascarenhas ${ }^{2 *}$, Paulo V. Peixoto ${ }^{3}$, Regina R. Ramadinha ${ }^{4}$, Elise M. Yamasaki², \\ Samay Z.R. Costa ${ }^{2}$, David Driemeier ${ }^{5}$, Luciana Sonne ${ }^{5}$ and Ticiana N. França ${ }^{6}$
}

\begin{abstract}
Mascarenhas M.B., Peixoto P.V., Ramadinha R.R., Yamasaki E.M., Costa S.Z.R., Driemeier D., Sonne L. \& França T.N. 2014. Immunohistochemical study of genital and extragenital forms of canine transmissible venereal tumor in Brazil. Pesquisa Veterinária Brasileira. 34(3):250-254. Programa de Pós-Graduação em Medicina Veterinária, Universidade Federal Rural do Rio de Janeiro, BR 465 km 7, Seropédica, RJ 23890-000, Brazil. E-mail:mm.bezerra@yahoo.com

Aiming to provide insight and discussing the problems related to the diagnosis and differential diagnosis of canine transmissible venereal tumor (CTVT), especially in its extragenital form, immunohistochemical evaluation was performed and a comparison was established by analysis of the microscopic appearance of 10 genital CTVTs and 13 exclusively extragenital CTVTs previously diagnosed by cytology and histopathology. CTVTs samples were incubated with biotinylated antibodies raised against specific membrane (anti-macrophage) and cytoplasmic antigens (anti-lysozyme, anti-S-100 protein, anti-vimentin and anti-CD18) and subsequently developed using streptavidin-biotin peroxidase and streptavidin-biotin-alkaline phosphatase methods. A strong reactivity with the anti-vimentin antibody was found in $100 \%$ of the tumors tested $(22 / 22)$. No reactivity was found for the anti-lysozyme, anti-macrophage, anti-S-100 protein and anti-CD18. No histopathological or immunoreactivity differences between genital and extragenital CTVTs were found. These findings do not corroborate the hypothesis of histiocytic origin of CTVT (no reactivity to anti-lysozyme, anti-macrophage and anti-CD 18 antibodies). In addition, the antibody panel used is useful to narrow the differential diagnosis for lymphomas, histiocytic tumors, amelanotic melanomas, and poorly differentiated epithelial neoplasias, among others.
\end{abstract}

INDEX TERMS: Canine transmissible venereal tumor, immunohistochemistry, round cell tumor, dog, pathology.

RESUMO.- [Estudo imuno-histoquímico de formas genitais e extragenitais do tumor venéreo transmissível canino no Brasil.] Com a finalidade de fornecer subsí-

${ }^{1}$ Received on November 7, 2013.

Accepted for publication on January 17, 2014

Parte da Dissertação de Mestrado do primeiro autor. Programa de Pós-Graduação em Medicina Veterinária, Universidade Federal Rural do Rio de Janeiro (UFRRJ), Seropédica, RJ, Brazil.

${ }^{2}$ Programa de Pós-Graduação em Medicina Veterinária, UFRRJ, BR-465 Km 7, Seropédica, RJ. *Corresponding author: mm.bezerra@yahoo.com

${ }^{3}$ Departamento de Nutrição Animal e Pastagem, UFRRJ, Seropédica, RJ.

${ }^{4}$ Departamento de Medicina e Cirurgia Veterinária, Instituto de Veterinária, UFRRJ, Seropédica, RJ.

${ }^{5}$ Departamento de Patologia Clínica Veterinária, Universidade Federal do Rio Grande do Sul (UFRGS), Av. Bento Gonçalves 9090, Porto Alegre, RS 91540-000, Brazil.

${ }^{6}$ Departamento de Epidemiologia e Saúde Pública, Instituto de Veterinária, UFRRJ, Seropédica, RJ. dios e discutir os problemas referentes ao diagnóstico e ao diagnóstico diferencial do tumor venéreo transmissível canino (TVTC), principalmente em sua forma extragenital, foi realizada a avaliação imuno-histoquímica e estabelecido termo de comparação com o aspecto microscópico em 10 TVTCs genitais e em 13 exclusivamente extragenitais previamente diagnosticados através de citologia e histopatologia. Os TVTCs foram testados para reagentes específicos de antígenos de membrana (anti-macrófago) e citoplasmáticos (anti-lisozima, anti-proteína S-100, anti-alfa-1-antitripsina, anti-vimentina e anti-CD18) com a utilização da técnica complexo avidina-biotina-peroxidase e estreptavidina-biotina-fosfatase Em 100\% dos tumores testados (22/22) com anticorpo anti-vimentina houve forte imuno-reatividade. Não houve reatividade para os anticorpos anti-lisozima, anti-macrófago, anti-proteína S-100 e anti-CD18. Não houve diferença histopatológica e de 
imuno-reatividade entre os TVTCs genitais e extragenitais. Estes achados indicam que os TVTCs avaliados não são de origem histiocítica (ausência de reatividade dos anticorpos anti-lisozima, anti-macrófago e anti-CD18). 0 painel de anticorpos utilizado é útil para o diagnóstico diferencial deste tumor com linfomas, tumores histiocíticos, melanomas amelanóticos e neoplasias de origem epitelial pobremente diferenciadas, entre outros.

TERMOS DE INDEXAÇÃO: Tumor venéreo transmissível, imuno-histoquímica, tumor de células redondas, cão, patologia.

\section{INTRODUCTION}

Canine trasmissible venereal tumor (CTVT) is a naturally occurring contagious round-cell neoplasia of the dog, located mainly on the external genital mucosae of both sexes (Cohen 1985). It has historically been given other names, such as venereal granuloma, canine condyloma, contagious lymphoma (Vermooten 1987), transmissible venereal sarcoma (Yang 1988) and Sticker`s sarcoma (Sticker 1904). CTVT can be transmitted by tumor cell implantation in mucous membranes during coitus, licking or sniffing (Yang 1988). Clinically this tumor appears as a solitary, red, friable, often "cauliflower-like mass" (Vermooten 1987, Rogers 1997, Papazoglou et al. 2001). Extragenital occurrence of CTVT without genital lesions has been reported in the oral (Bright et al. 1983, Ramadinha et al. 1993, Morrison 1998) and nasal cavity (Ndiritu et al. 1977, Bright et al. 1983, Morrison 1998, Papazoglou et al. 2001), conjunctiva and eye (Barron et al. 1963), skin and subcutis (Nielsen \& Kennedy 1990), tonsils (Theilen \& Madewell 1987), buccal mucosa and anal mucosa (Batamuzi \& Bittegeko 1991). This tumor has also been described with generalized metastases (Ramadinha et al. 1985). In these cases, it is usually not easy to carry out a differential diagnosis with other canine round cell tumor such as lymphomas, histiocytomas, poorly differentiated mast cell tumors, amelanotic epithelioid melanomas, and poorly differentiated carcinomas (Mozos et al. 1996, Lorimier \& Fan 2007). In addition, the exact cytogenetic origin of this tumor remained not clear. Mozos et al. (1996) and Marchal et al. (1997) demonstrated that CTVT cells express macrophage markers, suggesting that the tumor has a histiocytic origin, while others, have not confirmed these finding through immunohistochemical studies performed on frozen tissues (Goldschmidt \& Hendrick 2002, Gross et al. 2005). The purpose of the present study was to analyze the immunohistochemical pattern of spontaneous genital and extragenital CTVT, in order to provide support for the diagnosis and differential diagnosis of this neoplasm and to give additional information about its origin.

\section{MATERIALS AND METHODS}

Tissues samples. Samples of neoplastic tissues were collected from 23 dogs of different breeds, ages and sexes. In 10 dogs, the tumors were located in external genital mucosa and in 13 dogs the tumors had an extragenital location (7 skin, 4 oral cavity and 2 nasal cavity). Tissue samples were fixed in 10\% buffered formalin and embedded in paraffin. All tumors were diagnosed as CTVT after clinical, cytologic and histopathologic evaluation. In addition, the tumors had a complete clinical remission after the treatment with vincristine.

Immunohistochemical techniques. The streptavidin-biotin peroxidase and streptavidin-biotin alkaline phosphatase methods were used for immunohistochemical study. Tissue sections were deparaffinized and rehydrated. Endogenous peroxidase activity was blocked by treatment of the sections with 3\% H2O2 for 30 minutes at room temperature. After microwave treatment with citrate buffer, $\mathrm{pH} 6$, tissue sections were incubated with a $5 \%$ powdered milk for 30 minutes at room temperature. Primary antibodies used in this study and their specific dilutions are summarized in Table 1. After rinsing in phosphate-buffered saline (PBS), a streptavidin-immunoperoxidase staining procedure (Dako) was used for immunolabeling. The immunoreactions was observed with 3,3`diaminobenzidine substrate (Dako), except for the vimentin that was used a streptavidin biotin alkaline phosphatase method and the immunoreactions was observed with Permanente Red (DAKO Corp., Carpinteria, CA, Code 0695). Sections were counterstained with Harris's hematoxilin. Positive immunohistochemical controls for each one of the antibodies were used.

Table 1. Primary antibodies used in the immunohistochemical study

\begin{tabular}{lccccc}
\hline Specificity & Clone & Dilution & Incubation & Treatment & Source \\
\hline Anti-Lysozyme & Polyclonal & $1 / 100$ & Overnight $^{\text {Microwave }}$ & $\begin{array}{c}\text { Zymed - } \\
\text { Invitrogen }\end{array}$ \\
Anti-S-100 & Monoclonal & $1 / 50$ & $1 \mathrm{~h}$ & Microwave & $\begin{array}{c}\text { Zymed - } \\
\text { Invitrogen }\end{array}$ \\
$\begin{array}{l}\text { Anti-macro } \\
\text {-phage }\end{array}$ & Monoclonal & $1 / 50$ & $1 \mathrm{~h}$ & Microwave & $\begin{array}{c}\text { Invitrogen } \\
\text { Anti-CD 18 }\end{array}$ \\
Monoclonal & $1 / 20$ & $1 \mathrm{~h}$ & Microwave & $\begin{array}{c}\text { University } \\
\text { of California }\end{array}$ \\
Anti-Vimentin & Monoclonal & $1 / 200$ & Overnight & Proteinase $\mathrm{K}^{\mathrm{b}}$ & Dako
\end{tabular}

a Incubation with $0.1 \mathrm{M}$ citric acid ( $\mathrm{pH}$ 6) for $6 \mathrm{~min}$. in microwave; ${ }^{\mathrm{b}}$ Incubation with proteinase $\mathrm{K}$ for $5 \mathrm{~min}$ at room temperature.

\section{RESULTS}

The tumors presented as single or multiple lesions, sometimes multilobulated resembling cauliflower (Fig.1), infiltrative or pedunculated mass, occasionally ulcerated.

Based on histopathologic evaluation, tumors cells were large and round often growing in rows in a delicate stroma. They had large, round vesicular nuclei with single prominent nucleoli. The cytoplasm was pale, slightly granular or, microvacuolated, and amphophilic. The degree of intratumoral perivascular infiltration by mature lymphocytes, plasma cells, neutrophils and macrophages was quite variable. Mitotic figures were plentiful (Fig.2).

The results of the immunocytochemical study are summarized in Table 2.

All CTVTs analysed were negative for anti-lysozyme however infiltrating macrophages and neutrophils showed an intense immunoreactivity to this antibody that served as an internal positive control (Fig.3 and 4). The tumors (23 CTVTs) did not express anti-macrophage but, like anti-lysozyme, infiltrating macrophages and neutrophils showed intense membrane immunoreactivity to this antibody that served as an internal positive control (Fig. 5 and 6). Additionally, the 23 CTVTs, genital and extragenital location, were negative to anti-CD 18 antigen, although infiltrating macrophages and neutrophils usually showed an intense 


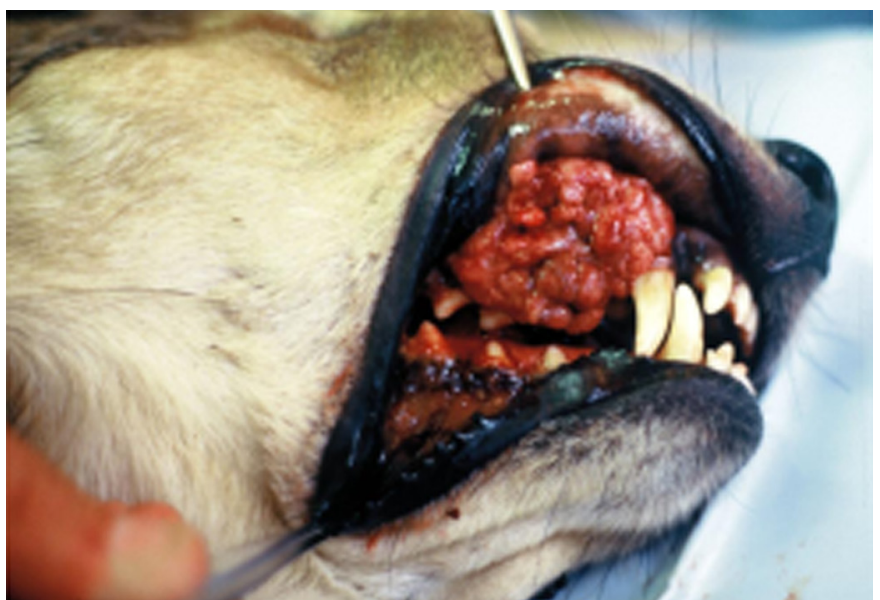

Fig.1. Extragenital CTVT (Dog 3). Multilobulated, ulcerated mass resembling cauliflower in the oral cavity of a dog.

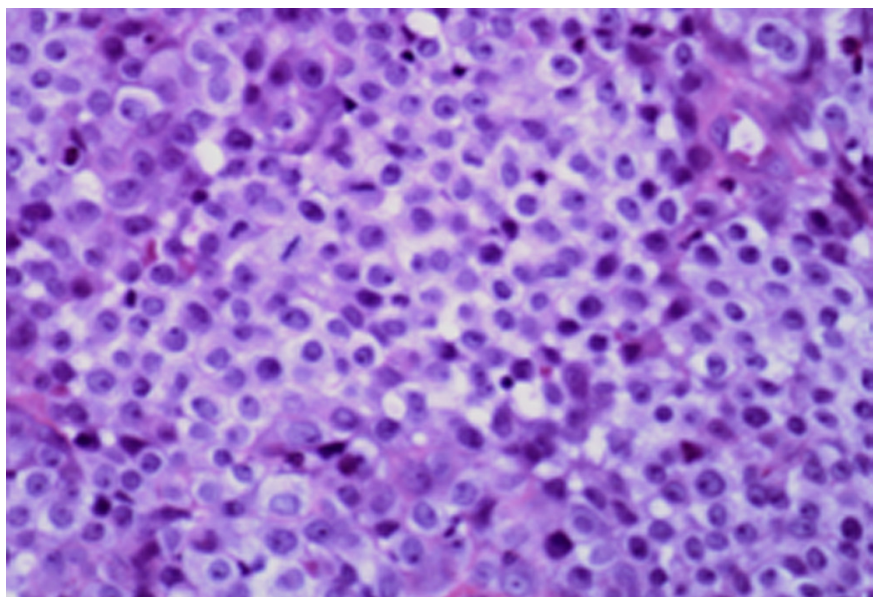

Fig.2. Genital CTVT (Dog 6). Tumor cells were round and had large, round vesicular nuclei with single prominent nucleoli and pale, amphophilic cytoplasm. Mitotic figures were frequent. HE, obj.40x.

Table 2. Immunohistochemical results of CTVT evaluation using anti-lysozyme, anti-vimentin, anti-anti-macrophage, anti-CD 18 and anti-S-100 antibodies

\begin{tabular}{lccccc}
\hline & \multicolumn{5}{c}{ Antibody } \\
\cline { 2 - 6 } CTVT & Lyso & Vim & Macro & CD 18 & S-100 \\
\hline Genital & $0 / 10$ & $9 / 9$ & $0 / 10$ & $0 / 10$ & $0 / 10$ \\
Extragenital & $0 / 13$ & $13 / 13$ & $0 / 13$ & $0 / 13$ & $0 / 13$
\end{tabular}

$\overline{\text { Lyso }=\text { Lysozyme; }}$ Vim = Vimentin; Macro = anti-macrophage; $\mathrm{S}-100=$ S-100 protein.

immunoreactivity (Fig.7). Immunoreactivity to vimentin was intense in the cytoplasm of more than $90 \%$ of the tumors cells of all CTVT analyzed (Fig. 8). The neoplasm studies did not express anti-S-100 protein although the positive control used (amelanotic melanoma) showed an intense immunoreactivity.

\section{DISCUSSION}

The 23 CTVTs studied exhibited morphological features that did not differ from those described in the literature (Nielsen \& Kennedy 1990, Scott, Miller \& Griffin 2001,

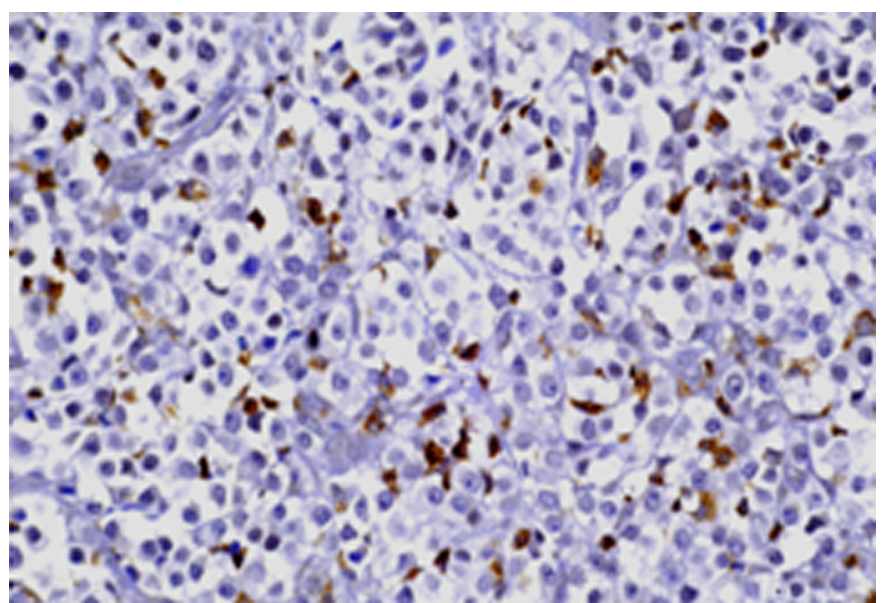

Fig.3. Genital CTVT (Dog 7). Unreactive tumor cells for antibody anti-lysozyme and intense immunoreactivity of infiltrating macrophages and neutrophils. Streptavidin-biotin peroxidase method, Harris's hematoxilin counterstain, obj.20x.

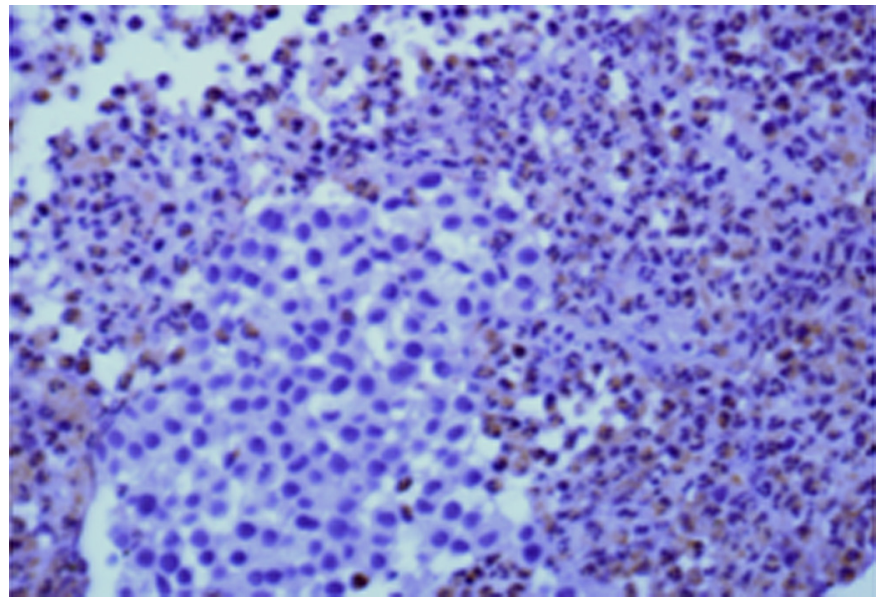

Fig.4. Extragenital CTVT (Dog 7). Unreactive tumor cells for antibody anti-lysozyme and intense immunoreactivity of infiltrating macrophages and neutrophils. Streptavidin-biotin peroxidase method, Harris's hematoxilin counterstain, obj.20x.

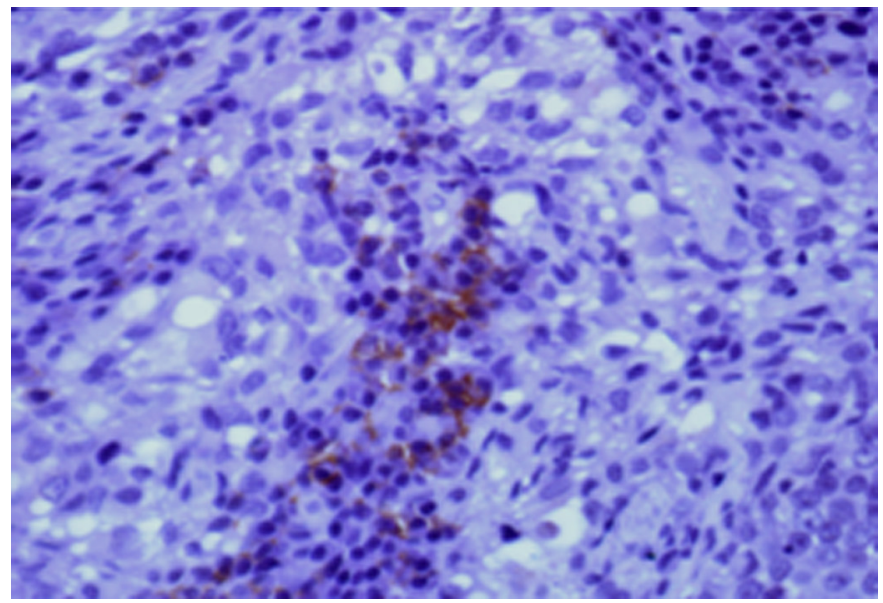

Fig.5. Extragenital CTVT (Dog 4). Notice intense staining of infiltrating macrophages and unreactivity tumor cells for antibody anti-macrophage. Streptavidin-biotin peroxidase method, Harris's hematoxilin counterstain, obj.20x. 


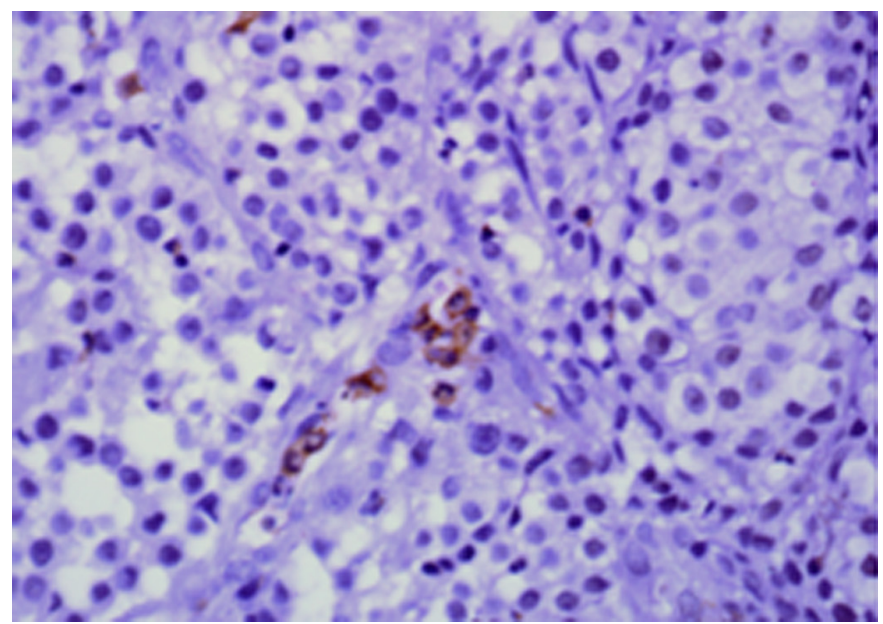

Fig.6. Genital CTVT (Dog 3). Intense staining of infiltrating macrophages and neutrophils and unreactivity tumor cells for antibody anti-macrophage. Streptavidin-biotin peroxidase method, Harris's hematoxilin counterstain, obj.20x.

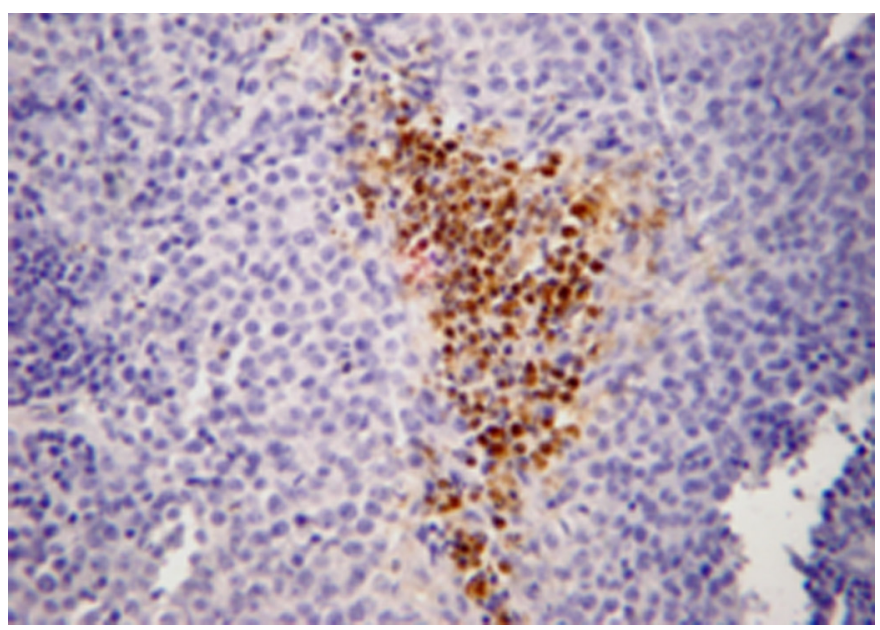

Fig.7. Extragenital CTVT (Dog 9). Intense staining of numerous infiltrating macrophages and neutrophils and unreactivity tumor cells for anti-CD18 antigen. Streptavidin-biotin peroxidase method, Harris's hematoxilin counterstain, obj.20x.

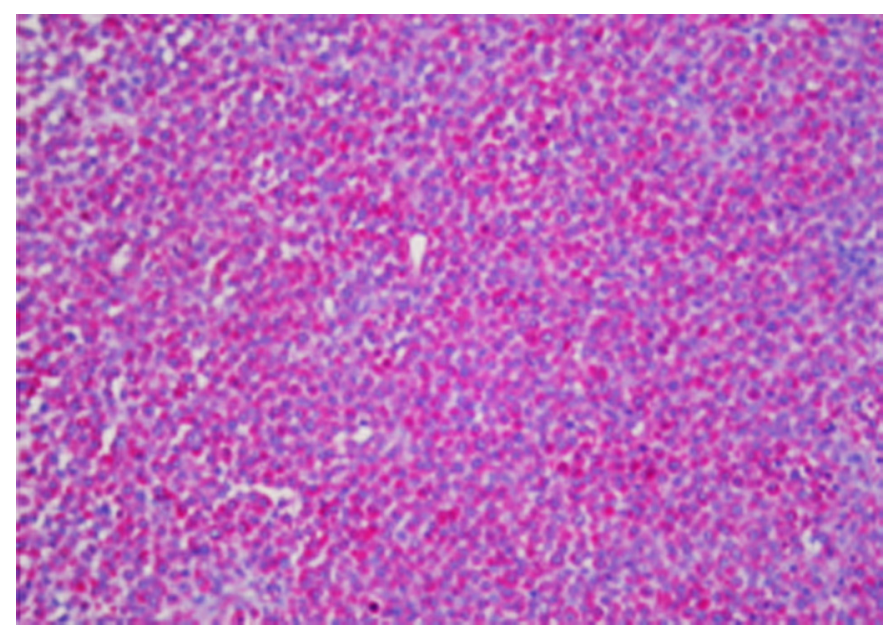

Fig.8. Extragenital CTVT (Dog 12). Intense staining of tumors cells for antibody vimentin. Streptavidin-biotin alkaline phosphatase method, Harris's hematoxilin counterstain, obj.10x.
Gross et al. 2005). Also, no histopathological differences were found between the selected genital and extragenital CTVT.

However, several differences were observed in the immunohistochemical analysis of the tumors with the previously described by Mozos et al. (1996) and Marchal et al. (1997). All CTVT studied were lysozyme-negative, whereas Mozos et al. (1996) found immunoreactivity in $40 \%$ of cases and Marchal et al. (1997) in 100\% of the tumours. Mozos et al. (1996) justified the differences found in the pretreatment of the slides (a microwave method or enzymatic digestion method), although the method in this study has been the same used by Marchal et al. (1997) (a microwave method). The heterogeneous immunoreactivity for lysozyme observed among tumors and individual cells in the same neoplasm has been related to the degree of cytoplasmic differentiation of neoplastic cells (Moore 1986), with poorly differentiated cells often being devoid of lysozyme (Moore \& Rosin 1986). Ramos Vara et al. (2008) describe that a cell marker of interest may not be expressed if the cell population is poorly differentiated. However it is more likely that the differentiation of CTVT cells could not explain these results, because all tumors had the typical histopathologic appearance, the cells were homogeneous, and did not differ from each other. Mozos et al. (1996) attributed the heterogenous pattern amoung individual tumor cells for lysozyme to the loss of antigens due to infiltrate immunoreactive histiocytes during CTVT cell proliferation. It is important to remember that infiltrating macrophages and neutrophils showed an intense immunoreactivity and they can be mistaken with the tumor cells, which may cause confusion in the interpretation. In this study, macrophages and neutrophils were strongly immuno-reactive for lysozyme and an initial analysis, less accurate, that were mistaken for tumor cells. Some authors had excluded this antibody from the panel of antibodies used for histiocytes because its inconsistent results (Morris et al. 2002). In the present study, none of the tumors were positive for lysozyme. Furthermore, lysozyme can not be useful for differential diagnosis of CTVT with others round cell tumors as previously mention (Mozos et al. 1996, Marchal et al. 1997). Adequate fixation is essential for immunohistochemistry to preserve antigenicity (Ramos-Vara et al. 2008). As infiltrating macrophages and neutrophils showed an intense immunoreactivity to this antibody, an inadequate fixation could be excluded. None of the CTVTs studied expressed anti-human macrophage but infiltrating macrophages and neutrophils showed an intense immunoreactivity to this antibody. Anti-human-macrophage is more one macrophage marker that is not expressed by CTVT. Like lysozyme and anti-human macrophage, all tumors analyzed were negative for CD18. Even though this antibody is a broad leukocyte marker, it is staining is prominent in histiocytic tumors (Lorimier \& Fan 2007). Currently, CD18 positive and CD3 and CD79 negative, to rule out lymphoid origin, are considered the most reliable markers for identifying histiocytic origin (Affolter \& Moore 2002). All CTVTs of our series showed intense immunoreactivity to vimentin in the cytoplasm of more than $90 \%$ of all tumors cells. These results are in agreement 
with those of previous reported (Sandusky \& Carlton \& Wightman 1987, Mozos et al. 1996, Marchal et al. 1997). Vimentin can be useful for differential diagnosis of CTVT with lymphomas and poorly differentiated carcinomas (Mozos et al. 1996). Vimentin is an intracellular fibrous protein found mainly in mesenchymal cells and considering the broad immunoreactivity pattern of vimentin, it can not help with the cytogenetic origin of CTVT (Marchal et al. 1997). None of the CTVT analyzed expressed S-100 protein as previously mentioned (Sandusky et al. 1987, Mozos et al. 1996) however, this antibody can be used to differentiate extragenital CTVT from amelanotic melanomas, which often express S-100 protein. In conclusion, our findings do not support the histiocytic origin suggested by Mozos et al. (1996) and Marchal et al. (1997) because none of the tumors were positive for lysozyme, anti-human macrophage and CD18. Gross et al. (2005), have not confirmed the histiocytic origin in immunohistochemical studies performed on frozen tissues. In addition, Goldschmidt \& Hendrick (2002) report that more recent studies indicate that the TVTC would consist of immature leukocytes, suggesting myeloid origin. Furthermore, microscopic evaluation revealed no differences between genital and extragenital CTVTs on histopathology or immunohistochemistry analyzes.

Acknowledgements.- To CNPq, FAPERJ and CAPES for the financial support and scholarship.

\section{REFERENCES}

Affolter V.K. \& Moore P.F. 2002. Localized and disseminated histiocytic sarcoma of dendritic cell origin in dogs. Vet. Pathol. 39:74-83.

Barron C.N., Saunders L.Z., Scibold H.R. \& Heath M.K. 1963. Intra-ocular tumors in animals. V. Transmissible venereal tumor of dogs. Am. J. Vet. Res. 24:1263-1269.

Batamuzi E.K. \& Bittegeko S.B.P. 1991. Anal and perianal transmissible venereal tumour in a bitch. Vet. Rec. 129:556.

Bright R.M., Gorman N.T., Probst C.W. \& Gorring R.L. 1983. Transmissible venereal tumor of the soft palate in a dog. J. Am. Vet. Med. Assoc. 183:893-895.

Cohen D. 1985. The canine transmissible venereal tumor: a unique result of tumor progression. Adv. Cancer Res. 43:75-112.

Goldschmidt M.H. \& Hendrick M.J. 2002. Tumors of the skin and soft tissue, p.45-117. In: Meuten D.J. (Ed.), Tumors in Domestic Animals. $4^{\text {th }}$ ed. Iowa State Press, Ames.

Gross T.L., Irhke P.J., Walder E.J. \& Affolter V.K. 2005. Skin diseases of the dog and cat. Clinical and histopathologic diagnosis. $2^{\text {nd }}$ ed. Blackwell Science, UK.

Lorimier L.P. \& Fan T.M. 2007. Canine Transmissible Venereal Tumor, p.799-804. In: Withrow S.J. \& MacEwen E.G. (Eds), Small Animal Clinical Oncology. $2^{\text {nd }}$ ed. W.B. Saunders, Philadelphia.
Marchal T., Chabanne L., Kaplanski C., Rigal D. \& Magnol J.P. 1997. Immunophenotype of the canine transmissible venereal tumor. Vet. Immunol. Immunopathol. 57(1/2):1-11.

Moore P.F. 1986. Utilization of cytoplasmic lysozyme as a histiocytic marker in canine histiocytic disorders. Vet. Pathol. 23:757-776.

Moore P.F. \& Rosin A. 1986. Malignant histiocytosis of Bersnese mountain dogs. Vet. Pathol. 23:1-10.

Morris J.S., McInnes E.F., Bostock D.E., Hoather T.M. \& Dobson J.M. 2002. Immunohistochemical and histopathologic features of 14 malignant fibrous histiocytomas from flat-coated retrievers. Vet. Pathol. 39:479-499.

Morrison W.B. 1998. Cancer in Dogs and Cats: medical and surgical management. Williams and Wilkins, Baltimore, p.795.

Mozos E., Méndez A., Gómez-Villamandos J.C., Martín De Las Mulas J. \& Pérez J. 1996. Immunohistochemical characterization of canine transmissible venereal tumor. Vet. Pathol. 33:257-263.

Ndiritu C.G., Mbogwa S.W. \& Sayer P.D. 1977. Extragenitally located transmissible venereal tumor in dogs. Mod. Vet. Pract. 58:940-946.

Nielsen S.W. \& Kennedy P.C. 1990. Tumor of the genital systems: transmissible venereal tumors of the dog, p.498-502. In: Moulton J.E. (Ed.), Tumors in Domestic Animals. California University Press, Berkeley.

Papazoglou L.G., Koutinas A.F., Plevraki A.G. \& Tontis D. 2001. Primary intranasal transmissible venereal tumor in the dog: a retrospective study of six cases. J. Vet. Med. A, Physiol. Pathol. Clin. Med. 48(7):391-400.

Ramadinha R.R., Ramadinha L.S. \& Kuner A. 1993. Tumor venéreo transmissível canino em cavidade oral sem lesão genital. Anais XV Congresso Brasileiro da Associação Nacional de Clínicos Veterinários de Pequenos Animais, Rio de Janeiro.

Ramadinha R.R., Vianna L.F.C.G. \& Ramadinha L.S. 1985. Tumor venéreo transmissível com metástases múltiplas: descrição de um caso. Revta Bras. Med. Vet. 145(6):178-180.

Ramos-Vara J.A., Kiupel M., Baszler T., Bliven L., Brodersen B., Chelack B., Czub S., Piero F.D., Dial S., Ehrhart E.J., Grahan T., Manning L., Paulsen D., Valli V.E. \& West K. 2008. Suggested guidelines for immunohistochemical techniques in veterinary diagnostic laboratories. J. Vet. Diagn. Invest. 20:393-413.

Rogers K.S. 1997. Transmissible venereal tumor. Comp. Cont. Educ. Pract. Vet. 19(9):1036-1045.

Sandusky G.E., Carlton W.W. \& Wightman K.A. 1987. Diagnostic immunohistochemistry of canine round cell tumors. Vet. Pathol. 24:495-499.

Scott D.W., Miller W.H. \& Griffin C.E. 2001. Neoplastic and non-neoplastic tumors, p.1365-1369. Muller and Kirk's Small Animal Dermatology. $6^{\text {th }}$ ed. W.B. Saunders, Philadelphia.

Sticker A. 1904. Transplantables lymphosarkom des Hundes (1904), p.498-502. In: Moulton J.E. (Ed.), Tumors in Domestic Animals. $3^{\text {rd }}$ ed, California University Press, Berkeley.

Theilen G.H. \& Madewell B.R. 1987. Clinical applications of cancer chemotherapy, p.183-196. In: Ibid. (Eds), Veterinary Cancer Medicine. $2^{\text {nd }}$ ed. Lea and, Febiger, Philadelphia.

Vermooten M.I. 1987. Canine transmissible venereal tumor (TVT): a review. J. South Afr. Vet. Assoc. 58:147.

Yang T.J. 1988. Immunobiology of a spontaneously regressive tumor, the canine transmissible venereal sarcoma: a review. Anticancer Res. 8(1):93-95. 